\title{
A Study on Customers Satisfaction towards Selective Sony Products with Special Reference to Coimbatore City
}

\author{
*Ms.S.Santhini, ** Mr.R.Jeeva Bharathi, **G.Meena Priya \\ *(Assistant Professor in Commerce, Dr.SNS Rajalakshmi College of Arts \& Science Coimbatore, India) \\ ** (Assistant Professor in Commerce, K.S.G College of Arts \& Science Coimbatore, India) \\ ** (Assistant Professor in Commerce, Dr.SNS Rajalakshmi College of Arts \& Science Coimbatore, India)
}

\begin{abstract}
Every customer has certain wants and a strong desire to satisfy them. The customer purchases certain goods under the impression that the goods would satisfy his wants. If the product fails to satisfy his wants, he will discard the product and switch over to some other product, which can effectively satisfy his needs. This being the case, every producer should satisfy the needs of the consumer effectively for the very existence of his enterprise. Particularly in a free enterprise economy, the customer is regarded as the King. That is why the study of customer satisfaction towards selective Sony products is necessary to identify whether selective Sony products are satisfying the needs of the customer effectively.

Key Words: Awareness, Customer Satisfaction, Factors, Problems
\end{abstract}

\section{INTRODUCTION}

A customer is a person who brings us his wants. It is our job to handle them profitability both to him and to ourselves. Customer satisfaction, a term frequently used in marketing, is a measure of how products and services supplied by a company meet or surpass customer expectation. Customer satisfaction can be stated as the number of customers, or percentage of total customers, whose reported experience with a firm, its products, or its services exceeds specified satisfaction goals.

\section{SCOPE AND LIMITATIONS OF THE STUDY}

The research has made an attempt to study the consumers needs, their fulfillment of needs. The observation should not be applied to area other than the surveyed field.

The findings are based only on the information given by the respondents.

\section{OBJECTIVES OF THE STUDY}

- To Study the awareness of various SONY Products

- To study the level of customer satisfaction towards selective SONY Products

- To understand the buying behavior of SONY Products

- To analyze the factors influencing the purchase of SONY Products

\section{RESEARCH DESIGN}

Descriptive research design in collecting and analyzing the data was carried out.

SAMPLE DESIGN: The method of data collection is through sample survey, convenience sampling is used in this survey.

SAMPLE SIZE: The size of the sample is 250

\section{ANALYTICAL TOOLS}

The following are the analytical tools applied for the analysis of the data collected.

a. Simple Percentage analysis

b. Chi-square tests

c. ANOVA and

d. Garrets Ranking method 


\section{ANALYSIS AND INTERPRETATION}

Analysis of distribution of the respondents on the basis of awareness of Sony product .The study was conducted on the basis to know the awareness of the respondents towards the Sony products.

AWARENESS ON PRODUCTS

TABLE NO: 1

\begin{tabular}{|l|c|}
\hline \multicolumn{1}{|c|}{ PRODUCTS } & $\begin{array}{c}\text { No: of respondents aware } \\
\text { ( out of 250 ) }\end{array}$ \\
\hline Television & 241 \\
\hline Cameras and Camcorders & 159 \\
\hline Vaio and Computing & 112 \\
\hline Personal Audio & 96 \\
\hline Sony Ericssion (Mobile) & 201 \\
\hline Play station & 81 \\
\hline
\end{tabular}

\section{Interpretation}

Analysis of awareness of the respondents shows that Television, Sony Ericssion (Mobile) and Cameras and Camcorders are known to more than $60 \%$ of the respondents.

\section{ANALYSIS OF DISTRIBUTION OF THE RESPONDENTS ON THE BASIS OF SOURCES OF AWARENESS OF SONY PRODUCT}

The study was conducted on the basis to know the sources of awareness of the respondents towards the Sony products. The sources available to the respondents are Radio, Television, Magazine, Newspaper, Friends \& Relatives and Online Advertisement

SOURCES OF AWARENESS

TABLE NO: 2

\begin{tabular}{|l|c|c|c|c|c|c|}
\hline SOURCE & $\begin{array}{l}\text { Televisio } \\
\mathbf{n}\end{array}$ & $\begin{array}{l}\text { Cameras } \\
\text { and } \\
\text { Camcord } \\
\text { ers }\end{array}$ & $\begin{array}{l}\text { Vaio and } \\
\text { Computi } \\
\text { ng }\end{array}$ & $\begin{array}{l}\text { Personal } \\
\text { Audio }\end{array}$ & $\begin{array}{l}\text { Sony } \\
\text { Ericssion } \\
\text { (Mobile) }\end{array}$ & $\begin{array}{l}\text { Play } \\
\text { Station }\end{array}$ \\
\hline Radio & 49 & 16 & 9 & 6 & 2 & 10 \\
\hline Television & 195 & 92 & 44 & 38 & 61 & 20 \\
\hline Magazine & 63 & 50 & 53 & 27 & 43 & 27 \\
\hline Newspaper & 42 & 35 & 24 & 32 & 48 & 11 \\
\hline $\begin{array}{l}\text { Friends\& } \\
\text { Relatives }\end{array}$ & 33 & 52 & 52 & 49 & 114 & 26 \\
\hline $\begin{array}{l}\text { Online } \\
\text { Advertisemen } \\
\text { t }\end{array}$ & 12 & 12 & 11 & 12 & 25 & 25 \\
\hline
\end{tabular}

\section{Interpretation}

Analysis of the sources of awareness of the respondents reveals that Television is the major source through which majority of the customers came to know about most of the Sony Products. Friends and Relatives and Newspaper are the sources through which mobile is known to the most of the respondents.

\begin{tabular}{|c|c|c|c|c|}
\hline & & $\begin{array}{l}\text { NY PRODUC' } \\
\text { LE NO: } 3\end{array}$ & & \\
\hline \begin{tabular}{|l} 
FACTORS \\
\end{tabular} & $\begin{array}{l}\text { COMPUTED CHI } \\
\text { SQUARE VALUE }\end{array}$ & $\begin{array}{c}\text { DEGREE OF } \\
\text { FREEDOM }\end{array}$ & P VALUE & INFERENCE \\
\hline Quality & 463.678 & 3 & 0.00 & Rejected \\
\hline Price & 440.335 & 4 & 0.00 & Rejected \\
\hline $\begin{array}{l}\text { Advertisement } \\
\text { factor }\end{array}$ & 206.678 & 3 & 0.00 & Rejected \\
\hline Durability factor & 213.399 & 3 & 0.00 & Rejected \\
\hline Model/style & 428.472 & 3 & 0.00 & Rejected \\
\hline
\end{tabular}




\section{Interpretation}

Analysis of the level of satisfaction reveals that majority of the respondents are highly satisfied with the Quality and Models/styles and they are satisfied with Price, Advertisement, and Durability.

\section{ANALYSIS OF THE LEVEL OF SATISFACTION OF THE RESPONDENTS TOWARDS SELECTIVE SONY PRODUCT}

TABLE No: 4

\begin{tabular}{|c|c|c|c|c|c|}
\hline factors & Sum of Squares & $\begin{array}{c}\text { Degree of } \\
\text { freedom }\end{array}$ & Mean Square & F & Sig. \\
\hline Age & 20.43 & 2 & 10.21 & 0.56 & 0.57 \\
\hline Income & 5.49 & 2 & 2.74 & 0.14 & 0.861 \\
\hline $\begin{array}{c}\text { Educational } \\
\text { status }\end{array}$ & 102.46 & 3 & 34.15 & 1.89 & 0.132 \\
\hline $\begin{array}{c}\text { Occupational } \\
\text { status }\end{array}$ & 20.80 & 3 & 6.933 & 0.37 & 0.770 \\
\hline
\end{tabular}

\section{Interpretation}

The level of satisfaction of respondents belonging to various age groups, Income, Educational Status and Occupational status reveals that respondents have an average score level of satisfaction on the features of Sony products.

\section{DISTRIBUTION OF THE RESPONDENTS ON THE BASIS OF BUYING BEHAVIOR (EARLIER \& NOW)}

TABLE NO: 5

\begin{tabular}{|l|c|c|c|c|}
\hline & \multicolumn{2}{|c|}{ Earlier used } & \multicolumn{2}{c|}{ Now Using } \\
\hline PRODUCT NAME & SONY & OTHERS & SONY & OTHERS \\
\hline Television & 71 & 88 & 146 & 13 \\
\hline Cameras and Camcorders & 14 & 40 & 45 & 9 \\
\hline Vaio and Computing & 16 & 20 & 28 & 8 \\
\hline Personal Audio & 26 & 22 & 39 & 9 \\
\hline Sony Ericssion (Mobile) & 46 & 44 & 75 & 15 \\
\hline Play station & 12 & 16 & 16 & 12 \\
\hline
\end{tabular}

\section{Interpretation}

The table No: 5 clearly indicates that currently more number of respondents use Sony Brand Products than earlier. This indicates that more number of customers is satisfied with the Sony Product.

\section{DISTRIBUTION ON THE BASIS OF RESPONDENTS MODE OF PURCHASE}

TABLE NO: 6

\begin{tabular}{|l|c|c|}
\hline Mode of Purchase & No of respondents & Percentage \\
\hline Cash & 161 & 64.4 \\
\hline Installment & 42 & 16.8 \\
\hline Exchange offer cum cash & 27 & 10.8 \\
\hline Exchange offer cum installment & 20 & 8.0 \\
\hline Total & $\mathbf{2 5 0}$ & $\mathbf{1 0 0}$ \\
\hline
\end{tabular}

\section{Interpretation}

The table reveals that $64.4 \%$ of the respondents purchase by cash and $16.8 \%$ of the respondents purchase by Installment and $10.8 \%$ of the respondents purchase by Exchange offer cum cash and $8.0 \%$ of the respondents purchase by Exchange offer cum installment. From the analysis it is concluded that the mode of payment for the majority of the respondents $(64.4 \%)$ is cash. 


\section{DISTRIBUTION ON THE BASIS OF RESPONDENTS PURCHASE DECISION}

TABLE NO: 7

\section{Interpretation}

\begin{tabular}{|l|c|c|}
\hline Who make the purchase decision & No of respondents & Percentage \\
\hline Self & 94 & 37.6 \\
\hline Family & 115 & 46.0 \\
\hline Friends \& Relatives & 41 & 16.4 \\
\hline Total & $\mathbf{2 5 0}$ & $\mathbf{1 0 0}$ \\
\hline
\end{tabular}

The table reveals that that $46.0 \%$ of the respondents say that purchase decision is taken by the family and $37.6 \%$ of the respondents say that purchase decision is taken by self and $16.4 \%$ of the respondents say that purchase decision is taken by friends \& relatives. From the analysis it is concluded that the majority of the respondents (46\%) say that purchase decision is made by the family members.

\section{ANALYSIS OF THE FACTORS INFLUENCING THE RESPONDENTS TO PURCHASE SONY PRODUCT}

In this research to find out what are the attributes that influence the purchase of Sony brand product the following attributes were taken in to study. Respondents were asked to rate (Rank) the attributes according to their perception. There rates (Rank) were converted in to percentile position as follows.

$$
\mathrm{P}=\frac{100(\mathrm{R}-0.5)}{\mathrm{N}}
$$

P: Percentile Position, R: Rank, N: No. of items

For these percentile positions, scores were taken from Garrelt's table and taken as value of the variable X, taking the no. of respondents assigning rates (Rank) $1,2, \ldots 10$ for each attributes or frequencies the total value for

\begin{tabular}{|c|c|c|c|c|c|c|c|c|c|c|c|c|c|}
\hline FACTORS & RATE & 1 & 2 & 3 & 4 & 5 & 6 & 7 & 8 & 9 & 10 & TOTAL & RANK \\
\hline & Score $(\mathrm{X})$ & 82 & 70 & 63 & 57 & 52 & 47 & 42 & 37 & 30 & 18 & & \\
\hline \multirow[t]{2}{*}{ Brand } & (F1) & 42 & 85 & 47 & 14 & 10 & 10 & 15 & 6 & 5 & 16 & & \\
\hline & XF1 & 3444 & 5950 & 2961 & 798 & 520 & 470 & 430 & 222 & 150 & 288 & 15433 & II \\
\hline \multirow[t]{2}{*}{ Quality } & (F2) & 139 & 34 & 32 & 16 & 6 & 3 & 4 & 3 & 8 & 5 & & \\
\hline & XF2 & 11398 & 2380 & 2016 & 912 & 312 & 141 & 168 & 111 & 240 & 90 & 17768 & I \\
\hline \multirow[t]{2}{*}{ Price } & (F3) & 21 & 47 & 55 & 22 & 22 & 14 & 14 & 10 & 14 & 31 & & \\
\hline & XF3 & 1722 & 3290 & 3465 & 1254 & 1144 & 658 & 588 & 370 & 420 & 558 & 13469 & III \\
\hline \multirow[t]{2}{*}{$\begin{array}{l}\text { Customer } \\
\text { Service }\end{array}$} & (F4) & 15 & 23 & 30 & 36 & 32 & 33 & 20 & 23 & 23 & 15 & & \\
\hline & XF4 & 1230 & 1610 & 1890 & 2052 & 1664 & 1551 & 840 & 851 & 690 & 270 & 12648 & IV \\
\hline \multirow[t]{2}{*}{ Price-Off Offer } & (F5) & 7 & 10 & 16 & 29 & 50 & 26 & 29 & 30 & 28 & 25 & & \\
\hline & XF5 & 574 & 700 & 1008 & 1653 & 2600 & 1222 & 1218 & 1110 & 840 & 450 & 11375 & VI \\
\hline \multirow[t]{2}{*}{ Gift coupons } & (F6) & & 7 & 10 & 29 & 20 & 37 & 46 & 41 & 34 & 26 & & \\
\hline & XF6 & 0 & 490 & 630 & 1653 & 1040 & 1739 & 1932 & 1517 & 1020 & 468 & 10489 & IX \\
\hline \multirow[t]{2}{*}{ Advertisement } & (F7) & 4 & 7 & 8 & 35 & 28 & 37 & 34 & 34 & 43 & 20 & & \\
\hline & XF7 & 328 & 490 & 504 & 1995 & 1456 & 1739 & 1428 & 1258 & 1290 & 360 & 10848 & VII \\
\hline \multirow{2}{*}{$\begin{array}{l}\text { Friends and } \\
\text { Relatives }\end{array}$} & (F8) & 1 & 8 & 10 & 26 & 37 & 29 & 33 & 43 & 30 & 33 & & \\
\hline & XF8 & 82 & 560 & 630 & 1482 & 1924 & 1363 & 1386 & 1591 & 900 & 594 & 10512 & VIII \\
\hline \multirow[t]{2}{*}{$\begin{array}{l}\text { Need of the } \\
\text { family }\end{array}$} & (F9) & 18 & 14 & 18 & 29 & 26 & 35 & 27 & 25 & 37 & 21 & & \\
\hline & XF9 & 1476 & 980 & 1134 & 1653 & 1352 & 1645 & 1134 & 925 & 1110 & 378 & 11787 & $\mathrm{~V}$ \\
\hline $\begin{array}{l}\text { Different } \\
\text { models\&styles. }\end{array}$ & (F10) & 6 & 18 & 22 & 15 & 22 & 23 & 29 & 31 & 29 & 55 & & \\
\hline
\end{tabular}
each attributes was obtained on the basis of the total the ranks were assigned. The table below gives the ranks.

TABLE NO: 8

\section{Interpretation}

Quality, Brand and price are the first, second and third attribute which influenced the majority of the respondents to purchase Sony products. 


\section{SUGESSTIONS}

- The most of the respondents were highly satisfied with the quality of the Sony products. So it is suggested that same standards is to be maintained.

- From the study it is suggested to modify the price of the product competitively. So this factor has to be improved with a view to attract more customers and to retain the existing customers.

- The manufacturers should introduce more advertisement tactics to induce the people to prefer a particular brand.

\section{CONCLUSION}

The study is aimed at measuring customer satisfaction towards selective Sony products with special reference to Coimbatore City. Marketing starts before production and continues after sales. Marketing is the process of creating customers. Sony product is loved by each and everyone irrespective of age group is clear down by this study. The important attribute of the product is quality and prices have received favorable appreciation from the respondents. Product attributes like durability and customer service have also been appreciated. It is certified that the customer satisfaction concept is an unpredictable one in any kind of marketing but this study has attempt its best to reveal the same.

\section{BIBLIOGRAPHY}

Books for references

[1]. Philip Kotler "Marketing Research Management” Prentice hall Inc. Eagle wood Cliffs, USA, April 1992

[2]. Rajan Nair, "Marketing Management". Sultan Chand publications, New Delhi, 1987

[3]. S.A.Sherlakar, "Marketing Management", Himalaya Publishing House, Bombay, Delhi, Nagpur, 2002

\footnotetext{
Websites:

[4]. www.google.com

[5]. www.consumergoods.com

[6]. www.sonyindia.com

[7]. www.durablegoods.co.in
}

\section{Journals}

[8]. Journal of Marketing Research, 1996 P.335-363

[9]. Indian Journal of Marketing Vol 34 No.1 Jan 2004

[10]. Journal of Consumer Research, Dec 1991 